\title{
Effect of Christian Related Music on Choice of Music as a Study Subject by Muslim Students in Mombasa County, Kenya
}

\author{
Sumba B. Shitambasi
}

\author{
Department of Journalism and Communication, \\ Masinde Muliro University of Science and Technology, 190 - 50100 Kenya
}

Corresponding author details: Sumba B. Shitambasi; bshitambasi@mmust.ac.ke

\begin{abstract}
The purpose of this study was to evaluate the content of the secondary school music curriculum to establish the effect of the presence of Christian related music in the curriculum on the choice of Music as a study subject by Muslim students in Mombasa County, Kenya. The study used a survey research design. The sample population consisted of 27 participants as follows: 2 music teachers, 8 students, 8 parents, 1 Kenya Institute Curriculum Development Officer at the national level, 1 Quality Assurance and Standard Officer and 7 career masters. Data was collected through questionnaires, interviews and focus group discussion, which was analysed using both qualitative and quantitative methods. Findings show that Christian beliefs compete with Islamic beliefs thus Muslim students find it offensive to pursue the subject and learn Christian related music and values therein. In conclusion, Christianity and Islamic beliefs are two dominant religions that are competing rather than complementing religions; Muslim students find it hard to pursue music subject due to the elements of Christian related music in the curriculum. The study recommends that the choice of music subject by Muslim students is dependent on the provision of Islamic music in the music curriculum and must be incorporated to attract their enrolment.
\end{abstract}

Keywords: curriculum; Christian music; Muslim

\begin{abstract}
INTRODUCTION
Globally, there exists a serious issue of Muslim student enrolment in music education. Indicators are based on issues of low-class enrolment numbers, low levels of student interest in music subject, and failed recruitment strategies by learning institutions (Harden, 2006). In the $\mathrm{UK}$, music subject is a compulsory part of the national curriculum, however, the study has shown that several schools have allowed Muslim children to be withdrawn from music lessons by their parents (Halstead, 2017). According to Harris (2006) and Iszak (2013), most Muslims parents do not know why they withdraw their children from music lessons. There is a Muslim religious norm that perceives music as an unacceptable subject.
\end{abstract}

Conservative Muslim scholars prohibit the use of musical instruments in music lessons yet instruments such as pianos are used in Churches. The Islamic religion is rigid in adapting to changing times of instrumental music and advancing new music technologies. The perception of learning music in schools goes against the norms and ideologies of Islam as per the saying of the prophet Mohamed. This has made it difficult for Muslim students to partake in music lesson in both primary and secondary schools. The incompatibility of Islam to music creates a massive gap in the education system considering Islam has spread widely worldwide.

As the world becomes more integrated, there is a growing concern amongst Muslim communities that sin is becoming the norm (Pieri et al., 2014).
Furthermore, the common features in forbidding sin across Muslim communities have appeared, often focusing on what are seen as moral issues such as music. Music has been the topic of much debate among Islamic scholars since 700 AD (Alamer, 2015). Today, within stereotyped characterizations of Islam, pleasure, debate and performing creativity find little space; rather mainstream discourses strongest signifiers of Islam are violence, fundamentalism, repression and joylessness (Salhi, 2013). The interpretations of playing and listening to music in Islam can be divided into three categories: permission, prohibition, and only songs without musical instruments accepted (Alamer, 2015).

Whilst it cannot be assumed that all Muslims have an issue with performing arts, Christian music, secular music, dance and drama in schools, there has been sufficient unease in Muslim communities for it to merit attention. Music presents an ethical dilemma for some Muslims and this needs to be recognized (Izsak, 2013). Muslim Scholars who prohibit playing music and/or singing support their judgment with the following verse: "However, there are, among men, those who purchase idle talks, without knowledge (or meaning), to mislead (men) from the Path of Allah and throw ridicule (on the Path): for such there will be a Humiliating Penalty" (Al-Quran, Luqman, 6) (Alamer, 2015).

In South and West Asia as well as in North Africa, strong correlations exist between music as an art form and Islamic 
manifestations of performance. Musical traditions in these regions have also been in a dialogic relationship with the interdictions and disapproval of Islamic orthodoxy (Salhi, 2013). Dance, like music, is also a highly contentious issue in Muslim culture. Solo dancing in the Muslim context of Herat might involve eroticism and negative perceptions while mass dancing is regarded as threatening and undesirable (Salhi, 2013). Music of the Turks before the Islamic era was composed of folk poems generally song with an instrument; however, some notation systems abjad- were improved in most theory music books after the Islamic era (Karabaşoğlu, 2013).

Muslim youths in the United States are searching for music that reflects their own experiences and disaffection, silence and political awareness (Asiyah \& Untari, 2014). It reiterates that Hip hop provides a perfect cultural medium to express such views and preserve to attempt and encourage and stimulate them to hold on to an Islamic identity. Contrary to Muslims, Christians make great use of musical instruments in Churches. Christian music is music that has been written to express either personal or communal belief regarding Christian life and faith (Westermeyer, 2013). Common themes of Christian music include praise, worship, penitence and lament (Strickler, 2015). Christian music is composed and performed for many purposes, ranging from aesthetic pleasure, religious or ceremonial purposes, or to a positive message as an entertainment product for the marketplace (Elisha, 2017). Among the most prevalent uses of Christian music are in church worship or other gatherings (Anderson, 2013). Most Christian music involves singing, whether by the whole congregation (assembly) or by a specialized subgroup (Friedmann, 2013; Chave \& Eagle, 2015).

In the West, the majority of Christian denominations use instruments such as an organ, piano, electronic keyboard, guitar, or other accompaniment, and occasionally by a band or orchestra, to accompany the singing (Edmondson, 2013). However, the study reiterates that some churches have historically not used instruments, citing their absence from the New Testament. During the last century or so several of these groups have revised this stance. The singing of the Eastern Orthodox is also generally unaccompanied, though in the United States organs are sometimes used as a result of Western influence (Miller \& Shahriari, 2013). The provision of gender restricted Christian musical education and the proscription of mixedgender music education by some strains of Islam narrows the opportunities for all children to receive musical education (Be, 2015). The scholars who have written about Christian music have not explained the extent to which the inclusion of Christian related music has affected the choice of music subject by Muslim students in Mombasa County which this research targeted to fill the gap.

\section{STATEMENT OF THE PROBLEM}

Muslim participating in music is an abomination as prescribed in the Quran and the teachings of prophet Muhammed. Most civilisation has had it rough encouraging Muslim students to pursue Music as a subject and a career Mombasa County, one of the coastal counties in Kenya with the highest population of Muslims, has a low enrolment of Muslim students in Music subject. Muslim students face difficulties in participating in music education in Kenya.
Christian music forms part of the Music subject curriculum yet it is not permitted in Islam reverence. Christian musical content has been influenced by religious practice, meaning and values that are not Islamic. Muslim students may find it challenging to perform Christian pieces or Muslim teaching may prohibit their participation.

\section{RESEARCH METHODOLOGY}

A descriptive survey research design was used in this study. Data were obtained from a sample rather than the entire population. The study area was Mombasa County; focusing on Muslim sponsored secondary schools offering Music subject. The target population consisted of all students in secondary schools in Mombasa County currently taking or once took music. According to the QASO, Mombasa County, there are forty-four (44) secondary schools in the county having a total of twenty thousand and five $(20,005)$ students. Out of the forty-four (44) schools, twenty-eight (28) are Muslim communitysponsored while sixteen (16) are non-Muslim community sponsored. Currently, there is only one school which offers music and has a population of eighty-seven (87) music students distributed as follows: form one forty-four (44) students, form two twenty-one (21) students, form threeten (10) students and form four-twelve (12) students. The accessible population consists of Muslim students in Mombasa County who once took music as a subject and dropped it. They were only eight (8) students, three (3) music teachers, one (1) KICD officer, county QASO and career masters.

Sample size determination was conducted through purposive sampling that selected all the form 3 and 4 Muslim students who took music at junior secondary and dropped it at senior secondary; they were 9 in total, the 3 music teachers in the county, the KICD officer at the national level and QASO at the county level were selected all through purposive sampling. 9 parents to form 3 and 4 Muslim students who dropped music were also purposively selected. $30 \%$ of career masters from the Muslim community-sponsored schools were part of the sample.

Data collection was carried out by questionnaires, interviews and focus group discussion (FGD). Besides, content analysis was used to get the data from KNEC annual reports, KCSE past papers and examination schedule documents. The equipment included a tape recorder and a camera. Validity was attained through questionnaires test-retest to check whether they generated the intended data as per the study objectives. Reliability was achieved through Cronbach's Alpha coefficient of 0.82 thus data reliability was assured in this study. Quantitative data were analysed using a statistical package for social scientists (SPSS) Version 25.0 and presented in tables form. Qualitative data were described verbatim and presented in a narration form.

\section{RESULTS AND DISCUSSION}

The majority of Christian denominations use instruments to accompany the singing. This, however, is not a similar belief in the Islamic religion. The researcher, therefore, sought to identify the effects of Christian related music on the choice of music subject by Muslim students. Table 1 illustrates the findings 
TABLE 1: Effects of Christian Related Music on Choice of Music Subject by Muslim Students

\begin{tabular}{|l|c|c|c|}
\hline \multicolumn{1}{|c|}{ Christian Music } & $\begin{array}{c}\text { Strong Agree or } \\
\text { Agree }\end{array}$ & Undecided & $\begin{array}{c}\text { Strongly Disagree } \\
\text { or Disagree }\end{array}$ \\
\hline $\begin{array}{l}\text { It is wrong for a Muslim student to learn Christian related } \\
\text { music }\end{array}$ & $62.5 \%$ & $12.5 \%$ & $25.0 \%$ \\
\hline $\begin{array}{l}\text { There is no problem for a Muslim student to learn Christian } \\
\text { music for examination purpose }\end{array}$ & $37.5 \%$ & $12.5 \%$ & $50.0 \%$ \\
\hline $\begin{array}{l}\text { The teaching of Christian related pieces has discouraged } \\
\text { Muslim students from taking music subject }\end{array}$ & $50.0 \%$ & $12.5 \%$ & $37.5 \%$ \\
\hline Muslim students enjoy performing Christian related music & $25.0 \%$ & $12.5 \%$ & $62.5 \%$ \\
\hline $\begin{array}{l}\text { Muslim students are slow learners of Christian related } \\
\text { music as compared to non-Muslims. }\end{array}$ & $37.5 \%$ & $25.0 \%$ & $37.5 \%$ \\
\hline $\begin{array}{l}\text { Muslim students never buy discs containing Christian music } \\
\text { to listen to }\end{array}$ & $62.5 \%$ & $0.0 \%$ & $37.5 \%$ \\
\hline $\begin{array}{l}\text { Most of the Muslim students who drop music do so as a } \\
\text { result of the requirement to sing Christian related music }\end{array}$ & $62.5 \%$ & $12.5 \%$ & $25.0 \%$ \\
\hline
\end{tabular}

The results in Table 1 , shows that the majority of the respondents felt that it was wrong for Muslim students to learn Christian related music (62.5\%). They further stipulated that it was problematic for Muslim students to learn Christian music for examination purpose (50.0\%). That is why the majority of Muslim students drop Music when transitioning to senior secondary level. Christian related music being used as learning aids have had a lot of hindrances to the advancement of music as a career choice.
The researcher computed the Kruskal-Wallis $\mathrm{H}$ test to determine the differences between the effect of Christian related music in secondary schools' music curriculum on the choice of music subject by Muslim students according to Muslim parental/guardian knowledge of child's previous engagement in music subject. Table 2 illustrates the findings.

TABLE 2: Kruskal-Wallis H test on the Effects of Christian Related Music on Choice of Music Subject by Muslim Students

\begin{tabular}{|c|c|c|c|}
\hline \multicolumn{4}{|l|}{ Test Statistics ${ }^{a, b}$} \\
\hline Variables & Kruskal-Wallis H & Df & Asymp. Sig. \\
\hline It is wrong for a Muslim student to learn Christian related music & 2.286 & 1 & .131 \\
\hline $\begin{array}{l}\text { There is no problem for a Muslim student to learn Christian music for } \\
\text { examination purpose }\end{array}$ & .914 & 1 & .339 \\
\hline $\begin{array}{l}\text { The teaching of Christian related pieces has discouraged Muslim } \\
\text { students from taking music subject }\end{array}$ & 1.429 & 1 & .232 \\
\hline Muslim students enjoy performing Christian related music & .571 & 1 & .450 \\
\hline $\begin{array}{l}\text { Muslim students are slow learners of Christian related music as } \\
\text { compared to non-Muslims. }\end{array}$ & 1.333 & 1 & .248 \\
\hline Muslim students never buy discs containing Christian music to listen to & 1.667 & 1 & .197 \\
\hline $\begin{array}{l}\text { Most of the Muslim students who drop music do so as a result of the } \\
\text { requirement to sing Christian related music }\end{array}$ & 2.286 & 1 & .131 \\
\hline
\end{tabular}

a. Kruskal Wallis Test

$b$. b. Grouping Variable: Are you aware that your son/daughter used to take music subject and has dropped it?

The results in Table 2 shows that there was no statistically significant difference between it being wrong for a Muslim student to learn Christian related music, $\mathrm{H}(1)=2.286 \quad 1$, $\mathrm{p}>.05$; there being no problem for a Muslim student to learn Christian music for examination purpose, $\mathrm{H}(1)=$ $.914, p>.05$; the teaching of Christian related pieces had discouraged Muslim students from choosing music subject, $\mathrm{H}(1)=1.429, \mathrm{p}>.05$; the Muslim students enjoyed performing Christian related music, $\mathrm{H}(1)=.571$, $\mathrm{p}>.05$; the Muslim students were slow learners of Christian related music as compared to non-Muslims, $\mathrm{H}(1)=1.333, \mathrm{p}>.05$; the Muslim students never buy discs containing Christian music to listen to, $\mathrm{H}(1)=1.667, \mathrm{p}>.05$; and that the most of the Muslim students who dropped music did so as a result of requirement to sing Christian related music, $\mathrm{H}(1)=2.286, \mathrm{p}$ $>.05$.

It was evident that the use of Christian related music in teaching music lesson influenced the choice of music subject by Muslim students. Key informant 1 interview stated that:

It is my strongest opinion that the lowest number of Muslim students choosing music is attributed to its curriculum, which violates Islamic music components. 
The performance of Christian music in my class had seen many Muslim students being reluctant to participate.

Yaylor (1999), noted that music notation taught in schools today originated in the Catholic Church in the west, whose chants have no relevance to Muslims. However, the Kenyan music curriculum does not overemphasise Christian related music, but, the teaching of its related pieces has serious interreligious implication discouraging many Muslim students from choosing Music subject. According to an FGD interview, a member stated that "Muslim students do not enjoy performing Christian music." Nevertheless, when required to learn music as an examinable subject, it has been proven that they are fast learners of Christian music as established by key informant 2 and key informant 3 . The only avenue where Muslim students encounter music lessons is during music classes. The competing religious biases have subjected many Muslim students to quit Music subject. Therefore, Muslim students can easily partake in Music subject as long as the music curriculum incorporates Islamic music. According to Asiyah \& Untari (2014), the Muslim youths in the United States are searching for music that reflects their own experiences and disaffection, silence and political awareness. The hip hop genre was established by the US Muslim youths to provide a perfect cultural medium to express such views and preserve to attempt and encourage and stimulate them to hold on to an Islamic identity (Westermeyer, 2013). The culture change with the Islam domain should also change to compel them to embrace the changing world dynamics and promote music studies. There is the hope of the Muslim sponsored school in Kenya embracing the music curriculum. In line with this, according to a key informant (Amukhale), in a personal interview, the former executive secretary of KMF (Kenya Music Festival), noted that initially, the festival music syllabus contained only Western set pieces and African folksongs. However, with the syllabus expansion to capture Islamic music, many Muslim stakeholders supported the festival as officials, adjudicators of Islamic music and sponsors.

\section{CONCLUSION}

Christian related music being used has had a lot of hindrances to the advancement of music as a career choice. Christianity and Islamic beliefs are two dominant religions that are competing rather than complementing religions. Muslim students and parents/guardians find it hard to pursue it due to the elements of Christian related music in the curriculum. The KICD and QAS department have contributed little or none to the incorporation of Islamic content in the music curriculum.

\section{RECOMMENDATION}

Christian religion competes rather than complementing Islamic religion, therefore, making it a challenge to have Muslims choosing music subject that has Christian related lessons. The choice of music subject is dependent on the provision of Islamic music, which should be incorporated in the music curriculum.

\section{REFERENCES}

[1] Alamer, S. M. (2015). Cultural Perspectives of Associating Music with Giftedness in Saudi Arabia. Canadian Social Science, 11(2), 8-15.

[2] Anderson, A. H. (2013). An introduction to Pentecostalism: global charismatic Christianity. Cambridge University Press.

[3] Asiyah, N., \& Untari, L. (2014). Islamic Hip Hop Music: A Translation of Muslim Identity Under Western Political Culture.

[4] Be, W. S. M. E. (2015). Intersecting social justices and music education. The Oxford handbook of social justice in music education, 7.

[5] Edmondson, J. (Ed.). (2013). Music in American life: An encyclopaedia of the songs, styles, stars, and stories that shaped our culture [4 volumes]: An encyclopaedia of the songs, styles, stars, and stories that shaped our culture. ABC-CLIO.

[6] Elisha, 0. (2017). Proximations of Public Religion: Worship, Spiritual Warfare, and the Ritualization of Christian Dance. American Anthropologist, 119(1), 73-85.

[7] Friedmann, J. L. (2013). Music in Biblical Life: The Roles of Song in Ancient Israel. McFarland.

[8] Halstead, J. M. (2017). Islamic Education in England. Handbook of Islamic Education. ed. Holger Daun-Reza Arjmand, 855-871.

[9] Harden, S. L. (2006). A Muslim perspective of instrumental music education in American public schools.

[10] Izsak, K. (2013). Music education and Islam: Perspectives on Muslim participation in music education in Ontario. The Canadian Music Educator, $54(3), 38$.

[11] Karabaşoğlu, C. (2013). Meshk: As a Traditional Method of Turkish Music Education. Procedia-Social and Behavioral Sciences, 106, 1834-1839.

[12] Miller, T., \& Shahriari, A. (2013). The Middle East: Islam and the Arab World, Iran, Egypt, Sufism, Judaism. In World Music (pp. 268-305). Routledge.

[13] Pieri, Z. P., Woodward, M., Yahya, M., Hassan, I. H., \& Rohmaniyah, I. (2014). Commanding good and prohibiting evil in contemporary Islam: cases from Britain, Nigeria, and Southeast Asia. Contemporary Islam, 8(1), 37-55.

[14] Salhi, K. (Ed.). (2013). Music, culture and identity in the Muslim world: Performance, politics and piety. Routledge.

[15] Strickler, J. (2015). Psalms of Lament as a Resource for Contemporary Christian Worship.

[16] Westermeyer, P. (2013). Music and spirituality: reflections from a Western Christian perspective. Religions, 4(4), 567-583 